\title{
Comparision of growth of mature all-female and mixed-sex Common carp (Cyprinus carpio L.) stocks in RAS
}

\author{
László Kovács $^{1}$ - Dániel Minya ${ }^{1}$ - Dávid Homoki ${ }^{1}$ - Odunayo Abigeal Toviho ${ }^{1}$ - Áron Molnár ${ }^{1}$ - \\ Milán Fehér ${ }^{2}$ - László Stündl ${ }^{3}$ - Péter Bársony ${ }^{2}$ \\ ${ }^{1}$ Doctoral School of Animal Science, University of Debrecen. \\ ${ }^{2}$ University of Debrecen Faculty of Agricultural and Food Sciences and Enviromental Management, Institute of Animal Science, \\ Biotechnology and Nature Conservation, Debrecen \\ ${ }^{3}$ University of Debrecen Faculty of Agricultural and Food Sciences and Enviromental Management, Institute of Food Technology, Debrecen \\ kovacs.laszlo@agr.unideb.hu
}

\section{SUMMARY}

The common carp (Cyprinus carpio L.) is the most important fish species in Hungary, representing more than $70 \%$ of the total Hungarian fish production. Common carp production is important not only in Hungary but in Middle-East Europe, as well as Southeast Asia. The majority of production comes from fishpond culture. If the production sector wants to meet the increasing customer demands, there is a need to intensify research on the intensive fish production opportunities, e.g. all-female common carp technologies. The all-female technology is one of a genommanipulation technology. Its production showed better growth rate than mixed-sex population in pond culture. Our experiment combined the recirculation aquaculture system $(R A S)$ and the all-female common carp stocks intensification technologies. The purpose of the experiment is to provide results about the growth of all-female common carp in RAS.

The experiment used the „Tatai grey scale type” land-race common carp stocks. We propagated two all-female stocks (T2 and T3) and a control group (TK). Due to the technological characteristics of RAS, the water quality parameters were the same for all treatments and corresponded to the technological tolerance of common carp.

The experimental period lasted between July 10, 2019 and November 20, 2019. Result of growth performance showed that the growth of mixedsex stock was significantly higher than all-female stocks; (Control=3692.0 $\pm 590.5 \mathrm{~g}, \quad \mathrm{T2}=3438.8 \pm 415.4 \mathrm{~g}, \mathrm{T3}=3294.1 \pm 659.1 \mathrm{~g}$ ). Feed conversation ratio (Control $=1.3 \pm 0.1 \mathrm{~T} 2=1.5 \pm 0.2 \mathrm{T3}=1.6 \pm 0.5)$ and $S G R \%($ Control $=0.8 \pm 0.0 \mathrm{~T} 2=0.7 \pm 0.1 \mathrm{T3}=0.7 \pm 0.1)$ were similar .

Based on the obtained results, it can be concluded the all-female common carp technology has neither advantages nor disadvantages compared to the mixed-sex stock. The all-female technology can be beneficial if consumers look for female common carps. It is worth continuing the experiment and examine how the stocks will perform above $3 \mathrm{~kg}$ body weight.

Keywords: Common carp, growth performance, all-female, mixed-sex

\section{INTRODUCTION}

Common carp (Cyprinus carpio L.) is the most important fish species in Hungary, representing more than $70 \%$ of the country's fish production (FAO, 2019). This species is widely produced in Middle-East Europe, as well as Southeast Asia, mostly in China. Majority of the production is carried out in earthen ponds but due to the continuous demand for carp fish farmers raise carp even in RAS or other "all year-round" culture systems.

One way for intensifying production is to apply genetically improved stocks, eg. monosex (all male or all female) or triploid (sterile) fish. Various genomic manipulation methods have been applied at many fish species as catfish (Silurus glanis) (Linhart et al., 2001), Atlantic salmon (Salmo salar) (Benfey, 2001), Rainbow trout (Oncorhynchus mykiss) (Blanc et al., 2001) and the common carp (Nagy et al., 1979; 1984) too.

One of genom-manipulation technology is the allfemale or all-male stocks propagation. It has many advantages, such a better reproduction, increased growth rate, more uniform stocks which can be advantageous for fish processing (Kocour et al., 2005). All-female technology is developed based on which sex has growth rate for the particular fish species. The male Nile tilapia (Oreochromis niloticus) have better growth rate (Ezaz et al., 2004), but the Atlantic salmon (Galbreath et al., 1994; 1995) and Common carp female stocks have better growth rate (Kocour et al., 2003; 2005). All-female and mixed-sex growth performance of some species (Nile tilapia, Amur catfish (Silurus asotus) have been examined (Dan et al., 2000). Due to the production of common carp, the all-female and mixed-sex stocks has been studied only under pond circumstances. The reason for the better growth rate of female common carps is the later sexual maturity. When the all-female common carp stocks became mature the differences of the mixed-sex stock will be disappear (Hulata et al., 1985).

Czech studies showed the all-female common carp stocks have $29.7 \%$ higher growth rate on the 1-year and 9.5\% higher growth on 2-year under European climate conditions (Kocour et al., 2003; 2005), while Israel's study showed that the all-female common carp stocks have $15 \%$ higher growth rate than mixed-sex stock under Mediterranean climate conditions (Cherfas et al., 1996).

These results applies only to pond fish culture. We examined the all-female and mixed-sex common carp growth performance in RAS. This has a shorter time interval for precision production, when the water quality and feed intake and population density were controlled. The aim of our experiment was to examine 
the efficacy of all-female common carp production technology in RAS.

\section{MATERIALS AND METHODS}

\section{Ethical approval}

Animal handling and experimental procedures followed the Directive 2010/63/EU of the European parliament and of the council of 22 September 2010 on the protection of animals used for scientific purposes (2010/63/EU).

\section{Experimental design}

The study was conducted at the Fish Biology Laboratory of the Faculty of Agriculture and Food Sciences and Environmental Management, University of Debrecen. All-female and mixed-sex group were propagated May 2018. For the fertilization of the allfemale stock (T2 and T3) we used gynogenetic (XX) sperm, and the control group (C) was fertilized with normal sperm. The fish used in the experiment were "Tatai grey scale" type.

\section{Experiment of growth performance (July 10 - November 20)}

The experiment presents 19 weeks of data from a longer, 1-year growth performance study. 7-10 pieces of 14-month-old common carp were placed in each of the tank in $1 \mathrm{~m}^{3} /$ tank capacity recirculation system. Each treatment had three replicates, we used 9 tank. We fed the fish with $4.5 \mathrm{~mm}$ particle size of commercial feed (38\% crude protein and $12 \%$ crude fat) and $4.5 \mathrm{~mm}$ particle size of self-made common carp feed $(37 \%$ crude protein and $10 \%$ crude fat) five times a day. The water temperature $($ mean $\pm \mathrm{SD})\left(24.73 \pm 1.41^{\circ} \mathrm{C}\right)$ and the level of dissolved oxygen $(5.47 \pm 0.90 \mathrm{mg} / \mathrm{l}$ and $65.74 \pm 8.76 \%$ ) were measured daily (Hama HQ 30D). In addition, nitrite and ammonium and other water quality parameters, were also measured daily $(\mathrm{HACH}$, DR 3900 photometer) (Table 1). During the experiment, the water quality parameters were corresponding to the requirements for optimal growth of common carp.

Table 1

Water quality parameters

\begin{tabular}{lr}
\hline Water temperature $\left({ }^{\circ} \mathrm{C}\right)$ & $24.73 \pm 1.41$ \\
Dissolved oxygen $(\mathrm{mg} / \mathrm{l})$ & $5.47 \pm 0.90$ \\
Dissolved oxygen $(\%)$ & $65.74 \pm 8.76$ \\
$\mathrm{pH}$ & $7.90 \pm 0.40$ \\
Total hardness $(\mathrm{gH})$ & $14.31 \pm 1.35$ \\
Carbonate $(\mathrm{kH})$ & $10.06 \pm 1.57$ \\
Ammonium $(\mathrm{mg} / \mathrm{l})$ & $0.09 \pm 0.20$ \\
Nitrite $(\mathrm{mg} / \mathrm{l})$ & $0.19 \pm 0.16$ \\
Phosphate $(\mathrm{mg} / \mathrm{l})$ & $0.86 \pm 0.61$ \\
\hline
\end{tabular}

\section{Examination of growth rates}

Average body weight (g) and average standard length (cms) were determined based on the measurements recorded during the individual measurements of fish. Weight of the fish were measured using VWR LP-6501 scale. Survival rate (\%) $=$ (number of fish at the end of the experiment $/$ number of fish at the beginning $x 100)$. Condition factor $=(100$ $\mathrm{x}$ body weight $(\mathrm{g})) /$ standard body length $(\mathrm{cms}) 3$. To examine the growth rate of the fish, the SGR\% specific growth rate $-\mathrm{SGR} \%=(\ln \mathrm{Wf}-\ln \mathrm{Wi}) / \mathrm{t} \times 100$, Wf refers to the final body weight $(\mathrm{g})$, Wi stands for the initial body weight $(\mathrm{g})$, and $\mathrm{t}$ indicates the number of days. The daily growth rate - DGR was presented for each treatment's daily biomass growth weight. DGR $(\mathrm{g} /$ day $)=(\mathrm{Wf}-\mathrm{Wi}) / \mathrm{t}$, Wf refers to the final body weight (g), Wi stands for the initial body weight $(\mathrm{g})$, and $\mathrm{t}$ indicates the number of days. In the formula FCR $(\mathrm{g} / \mathrm{g})$ $=\mathrm{F} /(\mathrm{Wf}-\mathrm{Wi})(\mathrm{g} / \mathrm{g}), \mathrm{F}$ refers to the amount of dry feed consumed during the experiment (g), Wf refers to the final body weight (g), and Wi stands for the initial body weight $(\mathrm{g})$.

\section{Statistical examinations}

Data analysis was done using IBM SPSS 22 program. Within the groups, the homogeneity test was performed with a Levene test $(\mathrm{P}<0.05)$. The effect of treatments on the body length and bodyweight of the stocks were determined using one-way ANOVA with LSD test $(\mathrm{P}<0.05)$.

\section{RESULTS}

The results of the experiment is presented in Table 2. At the start of the study, among the 14-month-old stocks there was no significant differences in body weight. At the end of the experiment the Control group had significantly higher average body weight; Control $=3692.0 \pm 590.5 \mathrm{~g} ; \quad \mathrm{T} 2$ all-female $3438.8 \pm 415.4 \mathrm{~g}$; and T3 all-female $3294.1 \pm 659.1 \mathrm{~g}$. The T2 all-female and T3 all-female group had higher average standard length all time during experiment. It showed the Control group had higher condition factor Control $=4.5 \pm 0.8$; as $\mathrm{T} 2$ all-female $=3.5 \pm 0.4$; $\mathrm{T} 3$ allfemale $=3.5 \pm 0.4$. It means the all-female groups was spindlier than the Control group.

The FCR $(\mathrm{g} / \mathrm{g})$ data of the Control $=1.3 \pm 0.1$ was lower than $\mathrm{T} 2$ all-female $=1.5 \pm 0.2$ and $\mathrm{T} 3$ allfemale $=1.6 \pm 0.5$, indicating that the Control group utilized the feed better. The SGR\% showed a similar pattern in the groups; Control $=0.8 \pm 0.0 ;$ T2 allfemale $=0.7 \pm 0.1$ and $\mathrm{T} 3$ all-female $=0.7 \pm 0.1$. 
The results of the experiment July 10 - November 20

\begin{tabular}{|c|c|c|c|}
\hline & Mixed-sex Control & T2 All-female & T3 All-female \\
\hline Initial average body weight (g) & $1359.1 \pm 209.4^{\mathrm{a}}$ & $1288.9 \pm 171.0^{\mathrm{a}}$ & $1281.1 \pm 191.0^{\mathrm{a}}$ \\
\hline Final average body weight (g) & $3692.0 \pm 590.5^{\mathrm{b}}$ & $3438.8 \pm 415.4^{\mathrm{ab}}$ & $3294.1 \pm 659.1^{\mathrm{a}}$ \\
\hline Initial average standard length $(\mathrm{cm})$ & $32.7 \pm 2.3^{\mathrm{a}}$ & $34.5 \pm 1.4^{\mathrm{b}}$ & $34.8 \pm 1.8^{\mathrm{b}}$ \\
\hline Final average standard length $(\mathrm{cm})$ & $43.6 \pm 3.0^{\mathrm{a}}$ & $46.1 \pm 1.6^{b}$ & $45.2 \pm 2.7^{\mathrm{b}}$ \\
\hline Initial condition factor & $3.9 \pm 0.5^{\mathrm{b}}$ & $3.1 \pm 0.2^{\mathrm{a}}$ & $3.0 \pm 0.2^{\mathrm{a}}$ \\
\hline Final condition factor & $4.5 \pm 0.8^{\mathrm{b}}$ & $3.5 \pm 0.4^{\mathrm{a}}$ & $3.5 \pm 0.5^{\mathrm{a}}$ \\
\hline $\mathrm{FCR}(\mathrm{g} / \mathrm{g})$ & $1.3 \pm 0.1$ & $1.5 \pm 0.2$ & $1.6 \pm 0.5$ \\
\hline SGR $(\%)$ & $0.8 \pm 0.0$ & $0.7 \pm 0.1$ & $0.7 \pm 0.1$ \\
\hline Survival (\%) & $83.3 \pm 5.8$ & $80.0 \pm 0.0$ & $96.7 \pm 5.8$ \\
\hline
\end{tabular}

$\mathrm{P}<0.05$

\section{DISCUSSION}

On the basis of the growth rate data, it can be said that the RAS can more effectively utilize the growth potential of common carp by reducing the culture period. We could make $3 \mathrm{~kg}$ average body weight common carp under 1.5 year in RAS contrary to the Central-European climate pond culture, where production takes about 3 years.

The results show that the Control group had significantly higher body weight at the end of the experiment. In the RAS the all-female stocks doesn't have better growth, as opposed to pond culture, where they have significantly better growth. According to our experiment, there were no advantages of the all-female stocks, because the sexual maturation was earlier which could be the reason for slower growth of the all-female stock in RAS, opposite to the pond culture, where there is later maturation and faster growth in the period before maturation.

The experiment continues; we will examine the growth of the all-female stocks continuously till sexual maturation

\section{ACKNOWLEDGEMENTS}

The work was supported by the European Regional and Development Fund and the Government of Hungary within the project GINOP-2.3.2-15-201600025.

The work/publication is supported by the EFOP3.6.3-VEKOP-16-2017-00008 project. The project is co-financed by the European Union and the European Social Fund.

\section{REFERENCES}

Benfey, T. J. (2001): Use of sterile triploid Atlantic salmon (Salmo salar L.) for aquaculture in New Brunswick, Canada. ICES Journal of Marine Science. 2. 58: 525-529.

Blanc, J.-Poisson, H.-Vallée, F. (2001): Covariation between diploid and triploid progenies from common breeders in rainbow trout, Oncorhynchus mykiss (Walbaum). Aquaculture Research. 7. 32: 507-516.

Cherfas, N.-Gomelsky, B.-BenDom, N.-Joseph, D.-Cohen, S.Israel, I.-Kabessa, M.-Zohar, G.-Peretz, Y.-Mires, D. (1996): Assessment of all-female common carp progenies for fish culture. Israeli Journal of Aquaculture-Bamidgeh. 3. 48: 149157.

Dan, N. C.-Little, D. C. (2000): The culture performance of monosex and mixed-sex new-season and overwintered fry in three strains of Nile tilapia (Oreochromis niloticus) in northern Vietnam. Aquaculture. 3-4. 184: 221-231.

Directive 2010/63/EU of the European Parliament and of the Council of 22 September 2010 on the protection of animals used for scientific purposes. Official Journal of the European Union. L 276/33. 20.10.2010.

Ezaz, M. T.-Myers, J. M.-Powell, S. F.-McAndrew, B. J.-Penman, D. J. (2004): Sex ratios in the progeny of androgenetic and gynogenetic YY male Nile tilapia, Oreochromis niloticus L. Aquaculture. 1-4. 232: 205-214.

FAO (2019): National Aquaculture Sector Overview, Hungary. http://www.fao.org/fishery/countrysector/naso_hungary/en

Galbreath, P. F.-Jean, W. S.-Anderson, V.-Thorgaard, G. H. (1994): Freshwater performance of all-female diploid and triploid Atlantic salmon. Aquaculture. 1-2. 128: 41-49.

Galbreath, P. F.-Thorgaard, G. H. (1995): Saltwater performance of all-female triploid Atlantic salmon. Aquaculture. 1-4. 138: 7785 .

Hulata, G.-Rothbard, S.-Itzkovich, J.-Wohlfarth, G.-Halevy, A. (1985): Differences in hybrid fry production between two strains of the Nile tilapia. The Progressive Fish-Culturist. 1. 47: 42-49.

Nagy, A.-Rajki, K.-Bakos, J.-Csanyi, V. (1979): Genetic analysis in carp (Cyprinus carpio) using gynogenesis. Heredity. 1. 43: 35.

Nagy, A.-Csanyi, V.-Bakos, J-Bercsényi, M. (1984): Utilization of gynogenesis and sex-reversal in commercial common carp breeding: Growth of the first gynogenetic hybrids. Aquacultura Hungarica. 4: 7-16.

Kocour, M.-Linhart, O.-Gela, D.-Rodina, M. (2005): Growth Performance of All-Female and Mixed-Sex Common Carp Cyprinus Carpio L. Populations in the Central Europe Climatic 
DOI: $10.34101 /$ actaagrar/1/3748

Conditions. Journal of the World Aquaculture Society. 1. 36: 103-113.

Kocour, M.-Linhart, O.-Gela, D. (2003): Results of comparative growing test of all-female and bisexual population in two-yearold common carp (Cyprinus carpio L.). Aquaculture International. 4. 11: 369-378.

Linhart, O.-Haffray, P.-Ozouf-Costaz, C.-Flajšhans, M.Vandeputte, M. (2001): Triploidization of European catfish (Silurus glanis L.) with heat-, cold-, hydrostatic pressure shocks and growth experiment. Journal of Applied Ichtyology. 17: 247255 . 